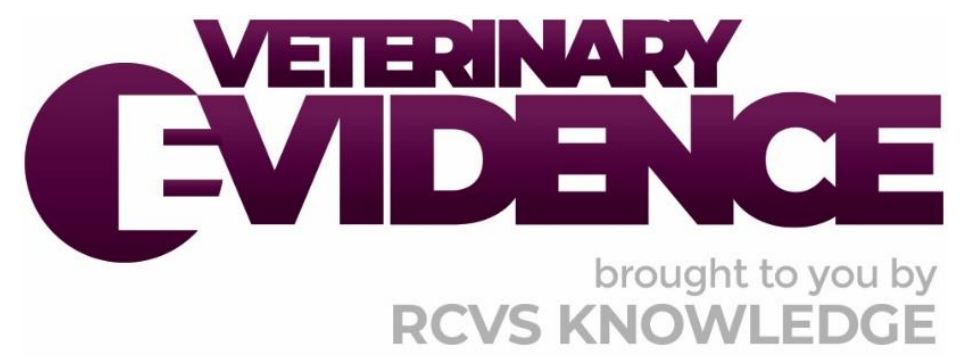

\title{
In cats and dogs with traumatic diaphragmatic rupture, does surgical timing affect outcome?
}

\author{
A Knowledge Summary by
}

Alison Robertson BVMS PGDip (VCP) MRCVS ${ }^{{ }^{*}}$

\footnotetext{
${ }^{1}$ University of Bristol, Langford Small Animal Referral Hospital, Langford House, Langford, Bristol, BS40 5DU

*Corresponding Author (alisonclrobertson@gmail.com)
}

ISSN: 2396-9776

Published: 10 Nov 2021

in: The Veterinary Evidence journal Vol 6, Issue 4

DOI: https://doi.org/10.18849/ve.v6i4.494

Reviewed by: Amanda Curtis (RVN) and April L Paul (DVM DACVECC)

Next Review Date: 03 Aug 2023 


\section{KNOWLEDGE SUMMARY}

\section{PICO question}

In cats and dogs with traumatic diaphragmatic rupture undergoing herniorrhaphy does surgical timing affect outcome?

\section{Clinical bottom line}

\section{Category of research question}

Prognosis

\section{The number and type of study designs reviewed}

Ten studies were critically appraised. All of these were retrospective case series

\section{Strength of evidence}

Zero

\section{Outcomes reported}

Overall, there is not sufficient evidence reporting if timing of surgical intervention has an effect on the mortality rate in dogs and cats with traumatic diaphragmatic rupture. Mortality rate was $6.8-50 \%$ in all cases

\section{Conclusion}

There is no statistically significant information available with only several retrospective studies published that are a low quality of evidence. Clinical practice can be reviewed based upon current evidence assessing timing of herniorrhaphy of traumatic diaphragmatic rupture. However, there are no clear recommendations and future studies are warranted

\section{How to apply this evidence in practice}

The application of evidence into practice should take into account multiple factors, not limited to: individual clinical expertise, patient's circumstances and owners' values, country, location or clinic where you work, the individual case in front of you, the availability of therapies and resources.

Knowledge Summaries are a resource to help reinforce or inform decision making. They do not override the responsibility or judgement of the practitioner to do what is best for the animal in their care.

\section{Clinical scenario}

A 2 year old female neutered domestic short-hair presents 30 minutes after being hit by a car. On presentation the cat is dyspnoeic and tachycardic at $250 \mathrm{bpm}$ with poor peripheral pulses. On thoracic auscultation heart sounds are dull on the left side and displaced caudodorsally on the right side. The abdomen feels 'empty' on palpation. Thoracic radiography and ultrasonography reveal the presence of a diaphragmatic rupture. The cat requires surgical repair of the diaphragm. Is the cat more likely to survive if herniorrhaphy is performed immediately, or if medical stabilisation is performed for 24 hours prior to surgery? 


\section{The evidence}

Evidence is lacking about the outcome of cats and dogs with traumatic diaphragmatic ruptures. There are few studies that assess outcome based on time from presentation to surgery. This may be due to many of these cases presenting to and being surgically repaired by their primary veterinarian. The papers discussed show no statistical correlation between length of time from presentation to surgery and survival to discharge. Clinical practice can be reviewed based upon current evidence; however, there are no clear recommendations and future studies are warranted. There are currently no prospective studies published, these may find a more significant outcome as less variables may be present.

\section{Summary of the evidence}

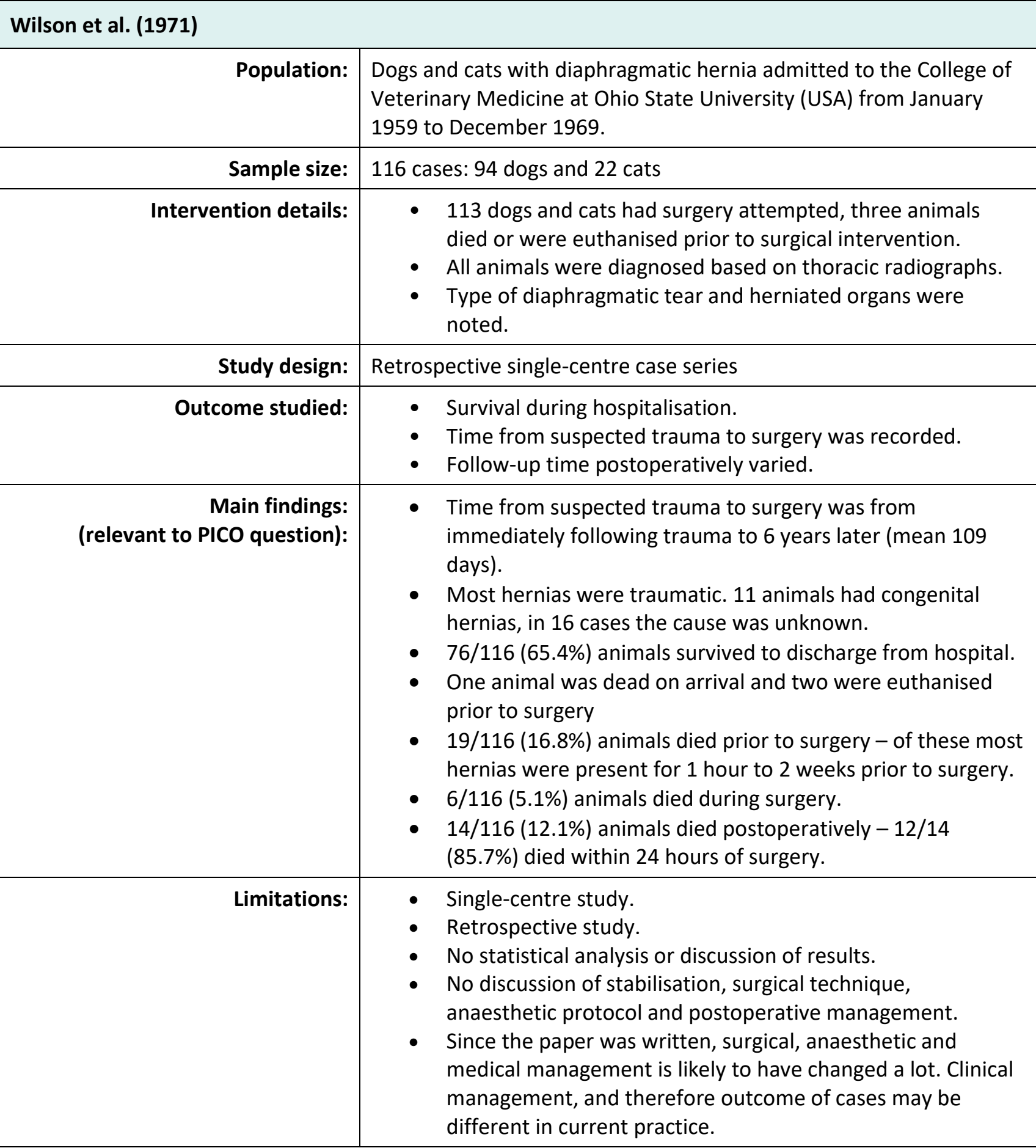




\begin{tabular}{|c|c|}
\hline \multicolumn{2}{|l|}{ Garson et al. (1980) } \\
\hline Population: & $\begin{array}{l}\text { Dogs and cats with traumatic diaphragmatic hernia admitted to } \\
\text { Glasgow University Veterinary School (UK) between January } 1972 \\
\text { and August } 1978 .\end{array}$ \\
\hline Sample size: & 56 cases: 23 dogs and 33 cats \\
\hline Intervention details: & $\begin{array}{l}\text { - } 53 \text { dogs and cats underwent surgery, three dogs died prior } \\
\text { to anaesthesia for herniorrhaphy. } \\
\text { - All animals diagnosed based on thoracic radiographs. } \\
\text { - } \quad \text { Anaesthetic protocols and supportive treatment varied. } \\
\text { - Midline celiotomy performed in all cases, two cases had } \\
\text { lateral thoracotomy. } \\
\text { - Type of diaphragmatic tear and herniated organs noted. } \\
\text { In cats evacuation of pneumothorax at the end of surgery } \\
\text { was performed by maximally expanding lungs prior to tying } \\
\text { of a purse string suture in the diaphragmatic tear. In dogs a } \\
\text { chest drain was placed. }\end{array}$ \\
\hline Study design: & Retrospective single-centre case series \\
\hline Outcome studied: & $\begin{array}{l}\text { Duration of clinical signs and signalment of each case } \\
\text { recorded. } \\
\text { - } \text { Follow-up time postoperatively varied. } \\
\text { - Discussed reasons patients had not survived to discharge. }\end{array}$ \\
\hline $\begin{array}{l}\text { Main findings: } \\
\text { (relevant to PICO question): }\end{array}$ & $\begin{array}{l}\text { - } 27 / 53 \text { (50.9\%) animals died or were euthanised. } \\
\text { - Most deaths occurred within } 24 \text { hours postoperatively, } \\
\text { - Time from admission to surgery was not recorded. }\end{array}$ \\
\hline Limitations: & $\begin{array}{l}\text { - Single-centre study. } \\
\text { - } \quad \text { Retrospective study. } \\
\text { - No discussion over time from presentation to surgery. } \\
\text { - } \quad \text { fome findings discussed as 'unremarkable', however these } \\
\text { - Did not discuss method of diagnosis of the diaphragmatic } \\
\text { rupture or the pathology leading to death or euthanasia. } \\
\text { - Varied stabilisation, surgical technique, anaesthetic protocol } \\
\text { and postoperative management. } \\
\text { Since the paper was written, surgical, anaesthetic and } \\
\text { medical management is likely to have changed a lot. Clinical } \\
\text { management, and therefore outcome of cases may be } \\
\text { different in current practice. }\end{array}$ \\
\hline
\end{tabular}

Schmiedt et al. (2003)

\begin{tabular}{|c|l|}
\hline Population: & $\begin{array}{l}\text { Cats that had surgical repair of traumatic diaphragmatic hernia at } \\
\text { the University of Tenessee and University of Georgia College of } \\
\text { Veterinary Medicine (USA) between 1991-2001. }\end{array}$ \\
\hline Sample size: & 34 cats \\
\hline
\end{tabular}




\begin{tabular}{|c|c|}
\hline Intervention details: & All cats underwent surgical repair of diaphragmatic rupture. \\
\hline Study design: & Retrospective multi-centre case series \\
\hline Outcome studied: & $\begin{array}{l}\text { Cause of hernia, breed, age, sex, clinical signs, duration of } \\
\text { hernia, location of diaphragmatic tear, organs herniated, } \\
\text { level of training of veterinarian performing the surgery, } \\
\text { placement of thoracic drain after surgery, postoperative } \\
\text { complications, time to discharge were recorded. } \\
\text { Duration of hernia was subjectively assessed as time from } \\
\text { traumatic event to surgical repair. } \\
\text { Long-term follow-up was obtained by telephone interview } \\
\text { with the owner or referring veterinary surgeon or by review } \\
\text { of medical records. }\end{array}$ \\
\hline $\begin{array}{l}\text { Main findings: } \\
\text { (relevant to PICO question): }\end{array}$ & $\begin{array}{l}\text { - There was no significant difference in mortality rates in cats } \\
\text { that had diaphragmatic hernia for } 0-24 \text { hours }(7 / 34 \text { ( } 20.6 \%) \\
\text { cats), } 1-7 \text { days }(17 / 34 \text { ( } 50 \%) \text { cats) or }>7 \text { days }(10 / 34(29.4 \%) \\
\text { cats) from trauma to repair. } \\
\text { - Mortality rate during hospitalisation was } 6 / 34(17.6 \%) \text { cats. } \\
\text { - Postoperative cardiac or respiratory arrest occurred in } 5 / 34 \\
\text { ( } 14.7 \%) \text { cats within } 48 \text { hours postoperatively. } \\
\text { - Mean duration of traumatic diaphragmatic hernia was } 17.6 \\
\text { days. } \\
\text { - Concurrent injuries were present in } 8 / 34(23.5 \%) \text { of cats, } \\
\text { mortality was significantly greater in these cats. } \\
\text { Long-term follow up available in } 17 / 34 \text { ( } 50 \%) \text { of cats, mean } \\
\text { duration was } 3.28 \pm 2.28 \text { years. } 10 / 14 \text { ( } 71.4 \%) \text { cats were } \\
\text { healthy, one cat had dyspnoea after strenuous exercise. } \\
3 / 14 \text { ( } 21.4 \%) \text { cats were dead, one was euthanised due to } \\
\text { urinary incontinence, one due to nasal haemorrhage, one } \\
\text { had an unknown cause of death. }\end{array}$ \\
\hline Limitations: & $\begin{array}{l}\text { - Retrospective study. } \\
\text { - Cases collected over long time period (1991-2001), surgical } \\
\text { procedures and medical management may have changed } \\
\text { within this time. } \\
\text { - Varied stabilisation, surgical technique, anaesthetic protocol } \\
\text { and postoperative management. } \\
\text { - Length of follow-up was variable and } 17 / 34(50 \%) \text { cases } \\
\text { were lost to long-term follow-up. }\end{array}$ \\
\hline
\end{tabular}

Minihan et al. (2004)

Population:
- Cats and dogs that underwent surgical repair of a chronic traumatic diaphragmatic hernia at Tufts University School of Veterinary Medicine or Angell Memorial Animal Hospital (USA) between 1987 and 1996.

- Diagnosis made by thoracic radiography in 48 animals, 10 animals had thoracic ultrasonography.

- Cases were considered chronic with:

- A history of known trauma, and clinical signs (coughing, tachypnoea, dyspnoea, vomiting, weight loss) for at least 2 weeks prior to surgery; OR 


\begin{tabular}{|c|c|}
\hline & $\begin{array}{l}\text { Obvious signs of chronicity at surgery (body wall } \\
\text { bruising, absence of haemothorax or } \\
\text { haemoabdomen, presence of adhesions or fibrosis } \\
\text { at hernia margins). }\end{array}$ \\
\hline Sample size: & 50 cases: 34 dogs and 16 cats \\
\hline Intervention details: & $\begin{array}{l}\text { - Anaesthetic protocol varied, all cases were mechanically } \\
\text { ventilated. } \\
\text { - All animals underwent exploratory laparotomy, 14/50 (28\%) } \\
\text { also underwent partial median sternotomy. }\end{array}$ \\
\hline Study design: & Retrospective multi-centre case series \\
\hline Outcome studied: & $\begin{array}{l}\text { Duration and type of clinical signs, initial clinical exam } \\
\text { findings and time from trauma to surgery were recorded. } \\
\text { - Postoperative complications were recorded. } \\
\text { - Follow-up time was variable, with long-term follow-up } \\
\text { available in } 34 \text { cases. }\end{array}$ \\
\hline $\begin{array}{l}\text { Main findings: } \\
\text { (relevant to PICO question): }\end{array}$ & $\begin{array}{l}\text { - Duration of clinical signs was } 1 \text { day to } 7 \text { years. } \\
\text { - } \quad \text { Time from trauma to surgical correction was } 2 \text { weeks to } 84 \\
\text { months (mean } 14.5 \text { months). } \\
\text { - } 43 / 50 \text { ( } 86 \% \text { ) of animals survived to discharge. } \\
\text { - } 2 / 50(4 \%) \text { of animals died or were euthanised during } \\
\text { surgery. } \\
\text { - } 5 / 50 \text { ( } 10 \% \text { ) of animals died or were euthanised } \\
\text { postoperatively during hospitalisation. } \\
\text { - } 30 / 43 \text { ( } 70 \% \text { ) of animals were alive at long-term follow-up } \\
\text { with no clinical signs related to the diaphragmatic hernia } \\
\text { (mean } 47 \text { months). } 3 / 43 \text { ( } 7 \% \text { ) of animals had died or were } \\
\text { euthanised at long-term follow-up (mean } 56 \text { months), the } \\
\text { remainder were lost to follow-up. }\end{array}$ \\
\hline Limitations: & $\begin{array}{l}\text { - Retrospective study. } \\
\text { - Cases collected over long time period (1987-1996), surgical } \\
\text { procedures and medical management may have changed } \\
\text { within this time. } \\
\text { - Varied stabilisation, surgical technique, anaesthetic protocol } \\
\text { and postoperative management. } \\
\text { - Groups outcome of all animals with diaphragmatic hernias } \\
\text { over } 14 \text { days, does not discuss outcome of different length } \\
\text { of clinical signs. }\end{array}$ \\
\hline
\end{tabular}

\begin{tabular}{|r|l|}
\hline \multicolumn{2}{|l|}{ Gibson et al. (2005) } \\
\hline Population: & $\begin{array}{l}\text { Dogs and cats undergoing surgical repair of traumatic diaphragmatic } \\
\text { hernia within 24 hours of admission to Ontario Veterinary Clinic, } \\
\text { University of Guelph (Canada), between January } 1990 \text { to December } \\
2002 .\end{array}$ \\
\hline Sample size: & 92 cases: 63 dogs and 29 cats \\
\hline Intervention details: & $\begin{array}{l}\text { - Cases underwent surgical repair of diaphragmatic rupture. } \\
\text { All cases underwent repair via a midline celiotomy and were } \\
\text { mechanically ventilated throughout the procedure. }\end{array}$ \\
\hline
\end{tabular}




\begin{tabular}{|c|c|}
\hline Study design: & Retrospective single-centre case series \\
\hline Outcome studied: & $\begin{array}{l}\text { To examine the effect of timing of surgical intervention on } \\
\text { perioperative survival rate. } \\
\text { - Intervention timing was objectively classified by: } \\
\circ \text { Time from trauma to admission } \\
0 \text { Time from trauma to surgery } \\
0 \quad \text { Time from admission to surgery } \\
\text { This was then categorised as early intervention ( }<24 \text { hours) or late } \\
(>24 \text { hours). } \\
\text { - Survival classified as discharge from hospital. Grouped as } \\
\text { alive or dead. Euthanised animals were included in the dead } \\
\text { group. } \\
\text { Cases with time from trauma to admission }<14 \text { days were } \\
\text { considered acute. } \\
\text { Cases with time from trauma to admission }>14 \text { days were } \\
\text { considered chronic. }\end{array}$ \\
\hline $\begin{array}{l}\text { Main findings: } \\
\text { (relevant to PICO question): }\end{array}$ & $\begin{array}{l}\text { - } 82 / 92(89.1 \%) \text { dogs and cats survived to discharge. } \\
\text { - } 84 / 92(91.3 \%) \text { dogs and cats received surgery within } 24 \\
\text { hours of admission. } \\
\text { Perioperative survival was not significantly associated with } \\
\text { time from trauma to admission (admitted }<24 \text { hours vs }>24 \\
\text { hours after trauma). } \\
\text { - Perioperative survival was not significantly associated with } \\
\text { time from trauma to surgery (undergoing surgery }<24 \text { hours } \\
\text { vs }>24 \text { hours after trauma). } \\
\text { - Perioperative survival was not significantly associated with } \\
\text { time from admission to surgery (undergoing surgery }<24 \\
\text { hours vs }>24 \text { hours after admission). } \\
\text { - Survival to discharge was not associated with time from } \\
\text { trauma to admission, time from trauma to surgery or time } \\
\text { from admission to surgery. }\end{array}$ \\
\hline Limitations: & $\begin{array}{l}\text { - Retrospective study. } \\
\text { - } \quad \text { Single-centre study. } \\
\text { surgical procedures and medical management may have } \\
\text { changed within this time. } \\
\text { - Poor control group (animals undergoing surgery }>24 \text { hours } \\
\text { after admission). } \\
\text { - Did not present data or discuss findings of animals } \\
\text { - } \quad \text { Did not discuss how diaphragmatic hernia was diagnosed. } \\
\text { - Varied stabilisation, surgical technique, anaesthetic protocol } \\
\text { and postoperative management. }\end{array}$ \\
\hline
\end{tabular}

Ozer et al. (2007)

Population:
- Cats undergoing diaphragmatic herniorrhaphy as treatment for suspected traumatic diaphragmatic hernia at Istanbul University Faculty of Veterinary Medicine (Turkey).

- Diagnosis made by positive contrast celiography. 


\begin{tabular}{|c|c|}
\hline Sample size: & 44 cats \\
\hline Intervention details: & $\begin{array}{l}\text { - All animals underwent general anaesthesia with a standard } \\
\text { protocol of gaseous induction via face mask with isoflurane } \\
\text { and positive pressure ventilation. A midline celiotomy was } \\
\text { performed for diaphragmatic herniorrhaphy. } \\
\text { - Postoperative plain radiographs were obtained for all cats. }\end{array}$ \\
\hline Study design: & Retrospective single-centre case series \\
\hline Outcome studied: & $\begin{array}{l}\text { Age, sex, breed, concurrent orthopaedic and soft tissue injuries, } \\
\text { radiographic changes, biochemical abnormalities, duration of } \\
\text { anaesthesia and surgery, organs herniated, location of rupture on } \\
\text { the diaphragm, perioperative complications were recorded. }\end{array}$ \\
\hline $\begin{array}{l}\text { Main findings: } \\
\text { (relevant to PICO question): }\end{array}$ & $\begin{array}{l}\text { - } \quad \text { Perioperative survival rate was } 41 / 44(93.2 \%) \text {. } \\
\text { - } \text { All deaths that occurred } 3 / 44(6.8 \%) \text {, were perioperative. }\end{array}$ \\
\hline Limitations: & $\begin{array}{l}\text { - Retrospective study. } \\
\text { - Single-centre. } \\
\text { - } \text { Only perioperative survival is discussed, it is not clear what } \\
\text { percentage of cats survived to discharge from hospital. } \\
\text { - Stabilisation of cases is not discussed. } \\
\text { The type of positive pressure ventilation that was used is not } \\
\text { and pressure given with each breath. } \\
\text { - } \quad \text { Anaesthetic length is not discussed. } \\
\text { The time frame that cases were collected over was not } \\
\text { recorded. }\end{array}$ \\
\hline
\end{tabular}

Besalti et al. (2011)

\begin{tabular}{|c|c|}
\hline Population: & $\begin{array}{l}\text { - Cats undergoing diaphragmatic herniorrhaphy as treatment } \\
\text { for traumatic diaphragmatic hernia at Ankara University, } \\
\text { Faculty of Veterinary Medicine (Turkey), between May } 2002 \\
\text { and April } 2010 \text {. } \\
\text { Diagnosis made by radiography, with some cases requiring } \\
\text { celiography or a barium swallow study for the confirmation } \\
\text { of diagnosis. }\end{array}$ \\
\hline Sample size: & 52 cats \\
\hline Intervention details: & $\begin{array}{l}\text { - Acute diaphragmatic rupture was defined as the suspected } \\
\text { trauma occurring }<14 \text { days prior to surgery. } \\
\text { - Chronic diaphragmatic rupture was defined as the suspected } \\
\text { trauma occurring }>14 \text { days prior to surgery. } \\
\text { - All cats received prophylactic cephalosporin and } \\
\text { dexamethasone prior to surgery. } \\
\text { - They all received standard protocols for general anaesthesia } \\
\text { mechanical ventilation, and midline celiotomy for } \\
\text { diaphragmatic herniorrhaphy. } \\
\text { - All cats were prescribed ketoprofen for } 3 \text { days } \\
\text { postoperatively. }\end{array}$ \\
\hline Study design: & Retrospective single-centre case series \\
\hline
\end{tabular}




\begin{tabular}{|c|c|}
\hline Outcome studied: & $\begin{array}{l}\text { - Age, sex, timing from suspected trauma to presentation, } \\
\text { clinical signs, concurrent injuries, location of diaphragmatic } \\
\text { tear, organs herniated, perioperative and postoperative } \\
\text { complications were recorded. } \\
\text { - Survival was classified as survival to discharge. } \\
\text { - Follow-up was performed in all cats to assess rate of } \\
\text { recurrence within the first } 10 \text { days postoperatively. }\end{array}$ \\
\hline $\begin{array}{l}\text { Main findings: } \\
\text { (relevant to PICO question): }\end{array}$ & 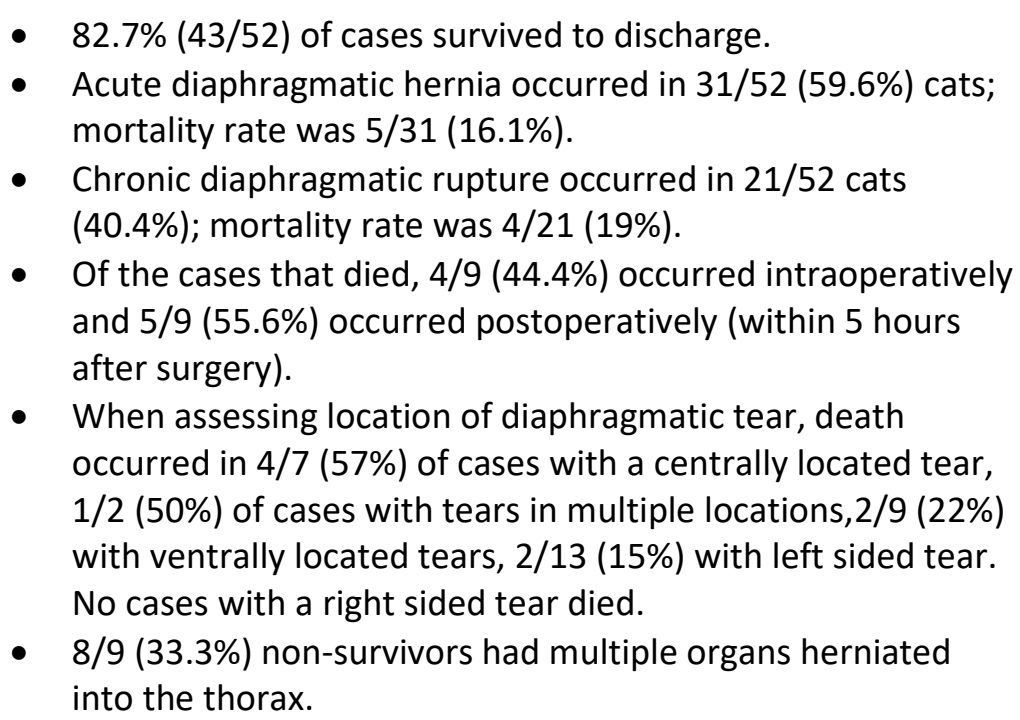 \\
\hline Limitations: & $\begin{array}{l}\text { - Retrospective study. } \\
\text { - } \text { Single-centre. } \\
\text { - } \text { discussed. } \\
\text { - Although it is discussed that cases were more likely to not } \\
\text { survive based on location of tear and having multiple organs } \\
\text { herniated, it is a small number of cases and therefore not } \\
\text { possible to assess causation. }\end{array}$ \\
\hline
\end{tabular}

Igna et al. (2014)

\begin{tabular}{|c|c|}
\hline Population: & $\begin{array}{l}\text { - Cats and dogs undergoing diaphragmatic herniorrhaphy as } \\
\text { treatment for traumatic diaphragmatic hernia at the Faculty } \\
\text { of Veterinary Medicine Timişoara (Romania), between } 2001 \\
\text { and } 2013 \text {. } \\
\text { - Diagnosis made by thoracic radiography and/or confirmed at } \\
\text { surgery. }\end{array}$ \\
\hline Sample size: & $\begin{array}{l}\text { - } 43 \text { cases: } 17 \text { cats and } 26 \text { dogs. } \\
\text { - All dogs and } 13 / 17(76.5 \%) \text { of cats had traumatic } \\
\text { diaphragmatic rupture. } \\
\text { - Three cats had a peritoneopericardial hernia and one cat } \\
\text { had a pleuroperitoneal hernia. }\end{array}$ \\
\hline Intervention details: & $\begin{array}{l}\text { All animals underwent general anaesthesia, manual or mechanical } \\
\text { ventilation, and midline celiotomy for diaphragmatic herniorrhaphy. } \\
\text { Four cases required a partial median sternotomy. }\end{array}$ \\
\hline Study design: & Retrospective single-centre case series \\
\hline
\end{tabular}




\begin{tabular}{|c|c|}
\hline Outcome studied: & $\begin{array}{l}\text { Age, sex, concurrent orthopaedic and soft tissue injuries, clinical } \\
\text { signs, organs herniated, timing from trauma to surgery, organs } \\
\text { herniated, type of diaphragmatic tear and location, survival to } \\
\text { discharge. }\end{array}$ \\
\hline $\begin{array}{l}\text { Main findings: } \\
\text { (relevant to PICO question): }\end{array}$ & $\begin{array}{l}\text { - } 32 / 43(74.4 \%) \text { of cases received surgical intervention within } \\
24 \text { hours of trauma. } \\
\text { - Survival to discharge was } 38 / 43(88.4 \%) \text { cases. }\end{array}$ \\
\hline Limitations: & $\begin{array}{l}\text { - } \text { Retrospective study. } \\
\text { - } \quad \text { Single-centre study. } \\
\text { surgical procedures and medical management may have } \\
\text { changed within this time. } \\
\text { - Stabilisation, surgical technique, anaesthetic protocol and } \\
\text { postoperative management are not discussed. } \\
\text { - Some cases were manually ventilated, varied volume and } \\
\text { pressure would be given each breath. } \\
\text { - Survival is described for all cases. There is no differentiation } \\
\text { between the outcome of traumatic versus congenital } \\
\text { diaphragmatic hernias. This is a limitation as cases with } \\
\text { traumatic hernias may present with concurrent injuries } \\
\text { which may affect patient stability and outcome. }\end{array}$ \\
\hline
\end{tabular}

Legallet et al. (2017)

\begin{tabular}{|c|c|}
\hline Population: & $\begin{array}{l}\text { Cats and dogs undergoing diaphragmatic herniorrhaphy as } \\
\text { treatment for traumatic diaphragmatic hernia at Texas A\&M } \\
\text { Veterinary Teaching Hospital (USA) between } 1 \text { October } 2001 \text { and } 31 \\
\text { April } 2014 .\end{array}$ \\
\hline Sample size: & 96 cases: 17 cats and 79 dogs \\
\hline Intervention details: & $\begin{array}{l}\text { Diagnosis made by thoracic radiography and } \\
\text { ultrasonography and confirmed at surgery. } \\
\text { - All animals underwent general anaesthesia, manual } \\
\text { ventilation, and midline celiotomy for diaphragmatic } \\
\text { herniorrhaphy. }\end{array}$ \\
\hline Study design: & Retrospective single-centre case series \\
\hline Outcome studied: & $\begin{array}{l}\text { - Age, sex, } \mathrm{SpO}_{2} \text { (oxygen saturation), blood lactate at } \\
\text { presentation, concurrent orthopaedic and soft tissue } \\
\text { injuries, duration of anaesthesia and surgery, organs } \\
\text { herniated, additional surgical procedures performed during } \\
\text { herniorrhaphy, perioperative and postoperative } \\
\text { complications were recorded. } \\
\text { - Intervention timing was objectively classified by: } \\
\quad \text { Time from trauma to admission } \\
\quad \text { Time from trauma to surgery } \\
\circ \quad \text { Time from admission to surgery } \\
\text { - Acute diaphragmatic hernias were present for }<14 \text { days } \\
\text { duration. } \\
\text { Chronic diaphragmatic hernias were present for }>14 \text { days } \\
\text { duration. }\end{array}$ \\
\hline
\end{tabular}




\begin{tabular}{|c|c|}
\hline & $\begin{array}{l}\text { - Animals grouped into survival to discharge or death during } \\
\text { hospitalisation, including euthanised animals. }\end{array}$ \\
\hline $\begin{array}{l}\text { Main findings: } \\
\text { (relevant to PICO question): }\end{array}$ & $\begin{array}{l}\text { - Time between trauma and admission, trauma and surgery, } \\
\text { and admission to surgery did not affect survival. } \\
\text { - } \quad \text { Perioperative survival rate was } 78 / 96 \text { ( } 81.3 \%)(15 / 17 \text { ( } 88.2 \%) \\
\text { cats and } 63 / 79(79.8 \%) \text { dogs). } \\
\text { - In acute cases } 10 / 12(83.3 \%) \text { cats and } 38 / 48(79.2 \%) \text { dogs } \\
\text { survived to discharge. } \\
\text { - In chronic cases } 5 / 5(100 \%) \text { cats and } 25 / 31(80.6 \%) \text { dogs } \\
\text { survived to discharge. } \\
\text { - } \quad \text { Animals that were oxygen dependent prior to surgery had a } \\
5 \text { times higher likelihood of mortality. } \\
\text { - } \quad \text { Animals with concurrent soft tissue injuries had a } 4.3 \text { times } \\
\text { higher likelihood of mortality. } \\
\text { - Animals with concurrent orthopaedic and soft tissue injuries } \\
\text { had a } 7.3 \text { times higher likelihood of mortality. } \\
\text { Increased anaesthetic and surgical time, due to concurrent } \\
\text { orthopaedic and soft tissue injuries, was associated with } \\
\text { higher mortality rates. }\end{array}$ \\
\hline Limitations: & $\begin{array}{l}\text { - Retrospective study. } \\
\text { - } \quad \text { Single-centre study. } \\
\text { surgical procedures and medical management may have } \\
\text { changed within this time. } \\
\text { - Varied stabilisation, surgical technique, anaesthetic protocol } \\
\text { and postoperative management. } \\
\text { - All cases manually ventilated, varied volume and pressure } \\
\text { - } \text { Mould be given each breath. } \\
\text { time as diaphragmatic herniorrhaphy, including elective } \\
\text { procedures such as neutering and portosystemic shunt } \\
\text { ligation. This likely affected outcome by increasing } \\
\text { anaesthetic length. }\end{array}$ \\
\hline
\end{tabular}

\section{Yaygingül et al. (2019)}

\begin{tabular}{|c|c|}
\hline Population: & $\begin{array}{l}\text { - Cats undergoing diaphragmatic herniorrhaphy as treatment } \\
\text { for traumatic diaphragmatic hernia at Adnan Menderes } \\
\text { University, Faculty of Veterinary Medicine (Turkey), between } \\
2016 \text { and } 2017 \text {. } \\
\text { - Diagnosis made by thoracic radiography, positive contrast } \\
\text { celiography was performed in one case. }\end{array}$ \\
\hline Sample size: & 15 cats \\
\hline Intervention details: & $\begin{array}{l}\text { - All animals were admitted to the intensive care unit and } \\
\text { received oxygen therapy and prophylactic antibiosis for } 24 \\
\text { hours prior to surgery. } \\
\text { - They all received standard protocols for general } \\
\text { anaesthesia, manual ventilation, and midline celiotomy for } \\
\text { diaphragmatic herniorrhaphy. }\end{array}$ \\
\hline
\end{tabular}




\begin{tabular}{|r|r|}
\hline & $\begin{array}{l}\text { All cases remained hospitalised for } 3 \text { days postoperatively. } \\
\text { During this time, they all received oxygen therapy, } \\
\text { methyprednisolone and salbutamol via nebulisation. }\end{array}$ \\
\hline Study design: & $\begin{array}{l}\text { All cats were prescribed cefazolin for } 1 \text { week } \\
\text { postoperatively. }\end{array}$ \\
\hline Outcome studied: & $\begin{array}{r}\text { Age, sex, body weight, timing from suspected trauma to } \\
\text { presentation, clinical signs, radiographic findings, biochemical } \\
\text { changes, location of diaphragmatic tear, organs herniated, } \\
\text { perioperative and postoperative complications were recorded. }\end{array}$ \\
\hline Main findings: & $\begin{array}{l}\text { Four cases died perioperatively; all of these had lung } \\
\text { lacerations and pleural effusion. }\end{array}$ \\
\hline Limitations: & $\begin{array}{l}\text { Mortality rate was 4/15 (26.7\%). } \\
\text { - Retrospective study. } \\
\text { - Single-centre study. }\end{array}$ \\
\hline $\begin{array}{l}\text { No discussion over timing from presentation to surgical } \\
\text { intervention. }\end{array}$
\end{tabular}

\section{Appraisal, application and reflection}

Overall, there is low quality of evidence assessing if performing herniorrhaphy within 24 hours of presentation affects the outcome of cats and dogs with traumatic diaphragmatic hernia. In the studies that assessed the time between trauma or hospital admission and surgical repair the timing of herniorrhaphy was not associated with survival to hospital discharge (Gibson et al., 2005; Legallet et al., 2017; and Schmiedt et al., 2003).

In one study assessing surgical repair of chronic diaphragmatic hernia, defined as being present for over 2 weeks prior to surgical repair, in-hospital mortality was $7 / 50$ (14\%) (Minihan et al., 2004). Another study found no difference in mortality in cats undergoing surgical repair within 24 hours, 1-7 days or over 7 days since trauma, with overall mortality of $6 / 34$ (17.6\%) (Schmiedt et al., 2003). Overall mortality is variable, with the lowest reported rate $3 / 44$ (6.8\%) (Ozer et al., 2007). The highest reported mortality rate was $27 / 53$ (50.9\%) (Garson et al., 1980); survival in this population was markedly worse that the cases in the remainder of the studies. This may reflect a change in approach to case management and treatment options available since publication. However, another older publication reported a mortality rate similar to more recent studies (Wilson et al., 1971).

The published data are retrospective studies with many clinical variables, with differences in individual disease severity and case management (Besalti et al., 2011; Garson et al., 1980; Gibson et al., 2005; Igna et al., 2014, Legallet et al., 2017; Minihan et al., 2004; Ozer et al., 2007; Schmiedt et al., 2003; Wilson et al., 1971; and Yaygingül et al., 2019). Varied disease severity is to be expected in this condition as it has a traumatic aetiology, and many cases presented with concurrent soft tissue and orthopaedic injuries. Multiple injuries were associated with outcome in two studies (Legallet et al., 2017; and Schmiedt et al., 2003), with an increase in mortality of these patients. Animals with concurrent injuries that underwent herniorrhaphy also had other surgical procedures performed under the same general anaesthesia. Several also had elective procedures performed, such as neutering. Increased anaesthesia time was linked with an increase in mortality (Legallet et al., 2017). In the same study, animals that required oxygen supplementation prior to surgery were less likely to survive. These findings suggest that systemic disease severity is associated with outcome in cats and dogs with traumatic diaphragmatic rupture.

Variables not assessed was the association between number and type of organs herniated into the thorax or the location of diaphragmatic tear and outcome. These were not linked to the PICO question to assess the timing of surgical intervention, therefore were not investigated as part of this review. 
In conclusion, in reviewing the available literature, there is no evidence to support that time to surgical intervention is associated with outcome in cats and dogs with traumatic diaphragmatic rupture.

\section{Methodology Section}

\begin{tabular}{|c|c|}
\hline \multicolumn{2}{|l|}{ Search Strategy } \\
\hline $\begin{array}{r}\text { Databases searched and dates } \\
\text { covered: }\end{array}$ & $\begin{array}{l}\text { CAB Abstracts 1973-2021 Week } 31 \\
\text { PubMed 1966-2021 Week } 31\end{array}$ \\
\hline Search terms: & $\begin{array}{l}\text { CAB Abstracts and PubMed: } \\
\text { 1. dog OR dogs OR canine OR cat OR cats OR feline } \\
\text { 2. diaphragm* } \\
\text { 3. hernia OR hernia OR rupture OR tear OR injury } \\
\text { 4. outcome* OR prognosis* OR survival* OR mortality* } \\
\text { 5. } 1 \text { and } 2 \text { and } 3 \text { and } 4\end{array}$ \\
\hline Dates searches performed: & 03 Aug 2021 \\
\hline
\end{tabular}

\section{Exclusion / Inclusion Criteria}

Exclusion: Not relevant, foreign, case reports, abstracts, reviews, book chapters, repeat of same relevant result within search

Inclusion: Relevant journal articles, accessed through University of Glasgow library 


\begin{tabular}{|c|c|c|c|c|c|c|c|c|c|}
\hline \multicolumn{10}{|c|}{ Search Outcome } \\
\hline Database & $\begin{array}{c}\text { Number of } \\
\text { results }\end{array}$ & $\begin{array}{c}\text { Excluded - } \\
\text { Not } \\
\text { relevant }\end{array}$ & $\begin{array}{c}\text { Excluded - } \\
\text { Foreign } \\
\text { (without } \\
\text { translation to } \\
\text { English) }\end{array}$ & $\begin{array}{l}\text { Excluded - } \\
\text { Case report }\end{array}$ & $\begin{array}{c}\text { Excluded - } \\
\text { Review }\end{array}$ & $\begin{array}{l}\text { Excluded - } \\
\text { Congress } \\
\text { proceedings } \\
\text { (abstract only) }\end{array}$ & $\begin{array}{c}\text { Excluded - } \\
\text { Book } \\
\text { chapter }\end{array}$ & $\begin{array}{l}\text { Excluded - } \\
\text { Repeated } \\
\text { result in } \\
\text { same search }\end{array}$ & $\begin{array}{c}\text { Total } \\
\text { relevant } \\
\text { papers }\end{array}$ \\
\hline $\begin{array}{l}\text { CAB } \\
\text { Abstracts }\end{array}$ & 229 & 188 & 3 & 12 & 11 & 3 & 1 & 1 & 10 \\
\hline PubMed & 83 & 68 & 1 & 7 & 1 & 0 & 0 & 0 & 6 \\
\hline \multicolumn{9}{|c|}{ Total relevant papers when duplicates removed } & 10 \\
\hline
\end{tabular}

DOI: https://doi.org/10.18849/ve.v6i4.494

next review date: 03 Aug 2023 


\section{CONFLICT OF INTEREST}

The author declares no conflict of interest.

\section{REFERENCES}

1. Besalti, O., Pekcan, Z., Caliskan, M. \& Aykut, Z.G. (2011). A retrospective study on traumatic diaphragmatic hernias in cats. Ankara Üniversitesi Veteriner Faukültesi Dergisi. 58(3), 175-179. DOI: https://doi.org/10.1501/Vetfak 0000002470

2. Garson, H.L., Dodman, N.H. \& Baker, G.J. (1980). Diaphragmatic hernia. Analysis of fifty-six cases in dogs and cats. Journal of Small Animal Practice. 21, 469-481.

3. Gibson, T.W.G., Brisson, B.A. \& Sears, W. (2005). Perioperative survival rates after surgery for diaphragmatic hernia in dogs and cats: 92 cases (1990-2002). Journal of the American Veterinary Medicine Association. 227(1), 105-109.

4. Igna, C., Schuszler, L., Sala, A., Bumb, D., Proteasa, A. \& Dascalu, R. (2014). Diaphragmatic hernia in dogs and cats: a report of 43 cases (2001-2013). Lucrări Ştiiţifice Medicină Veterinară. 47(4), 48-51. Available from: https://usab-tm.ro/utilizatori/medicinaveterinara/file/2014/simpozion/VOL \%20XLVII42014 complet.pdf [Accessed 03 Aug 2021].

5. Legallet, C., Theiman Makin, K. \& Selmic, L.E. (2017). Prognostic indicators for perioperative survival after diaphragmatic herniorrhaphy in cats and dogs: 96 cases (2001-2013). BMC Veterinary Research. 13(16). DOI: https://doi.org/10.1186/s12917-016-0926-y

6. Minihan, A.C., Berg, J. \& Evans, K.L. (2004). Chronic diaphragmatic hernia in 34 dogs and 16 cats. Journal of the American Animal Hospital Association. 40, 51-63.

7. Ozer, K., Guzel, O., Devecioglu, Y. \& Aksoy, O. (2007). Diaphragmatic hernia in cats: 44 cases. Medycyna Weterynaryjna. 63(12), 1564-1567. Available from: http://www.medycynawet.edu.pl/images/stories/pdf/pdf2007/122007/200712s15681571.pdf [ Accessed 03 Aug 2021].

8. Schmeidt, C.W, Tobias, K.M. \& McCrackin Stevenson, M.A. (2003). Traumatic diaphragmatic hernia in cats: 34 cases (1991-2001). Journal of the American Veterinary Medicine Association. 222(9), 12371240.

9. Wilson, G.P., Newton, C.D. \& Burt, J.K. (1971). A review of 116 diaphragmatic hernias in dogs and cats. Journal of the American Veterinary Medicine Association. 159(9), 1142-1145.

10. Yaygingül, R., Bozkan, Z., Bilgen Şen, Z., Kibar Kurt, B. \& Belge, A. (2019). Traumatic diaphragmatic hernia in cats: a retrospective study of 15 cases (2016-2017). Kocatepe Veterinary Journal. 12(2), 205212. DOI: https://doi.org/10.30607/kvj.493594 


\section{EVIIDEFeE

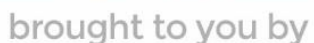 \\ RCVS KNOWLEDGE}

\section{Intellectual Property Rights}

Authors of Knowledge Summaries submitted to RCVS Knowledge for publication will retain copyright in their work, and will be required to grant RCVS Knowledge a non-exclusive license of the rights of copyright in the materials including but not limited to the right to publish, re-

publish, transmit, sell, distribute and otherwise use the materials in all languages and all media throughout the world, and to license or permit others to do so.

\section{Disclaimer}

Knowledge Summaries are a peer-reviewed article type which aims to answer a clinical question based on the best available current evidence. It does not override the responsibility

of the practitioner. Informed decisions should be made by considering such factors as individual clinical expertise and judgement along with patient's circumstances and owners' values. Knowledge Summaries are a resource to help inform and any opinions expressed within the Knowledge Summaries are the author's own and do not necessarily reflect the view of the RCVS Knowledge. Authors are responsible for the accuracy of the content. While the

Editor and Publisher believe that all content herein are in accord with current recommendations and practice at the time of publication, they accept no legal responsibility

for any errors or omissions, and make no warranty, express or implied, with respect to material contained within.

For further information please refer to our Terms of Use.

RCVS Knowledge is the independent charity associated with the Royal College of Veterinary Surgeons (RCVS). Our ambition is to become a global intermediary for evidence based veterinary knowledge by providing access to information

that is of immediate value to practicing veterinary professionals and directly contributes to evidence based clinical decision-making.

\section{https://www.veterinaryevidence.org/}

RCVS Knowledge is a registered Charity No. 230886.

Registered as a Company limited by guarantee in England and Wales No. 598443.

Registered Office: Belgravia House, 62-64 Horseferry Road, London SW1P 2AF

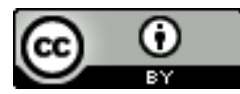

This work is licensed under a Creative Commons Attribution 4.0 International License 